\title{
BLOOD BIOCHEMISTRY REFERENCE VALUES FOR WILD JUVENILE LOGGERHEAD SEA TURTLES (CARETTA CARETTA) FROM MADEIRA ARCHIPELAGO
}

\author{
Cláudia Delgado, ${ }^{1}$ Ana Valente, ${ }^{2,5}$ Isabel Quaresma, ${ }^{3}$ Margarida Costa, ${ }^{4}$ and \\ Thomas Dellinger ${ }^{1}$ \\ ${ }^{1}$ Marine Biology and Oceanography Laboratory, University of Madeira, Portugal \\ 2 Departamento de Morfologia, Instituto de Biologia, Universidade Federal de Pelotas, CP 354, Campus Universitário \\ Capão do Leão, 96160-000, Rio Grande do Sul, Brazil \\ ${ }^{3}$ Direç̧ão Regional de Pescas, Secretaria Regional do Ambiente e Recursos Naturais, Funchal, Madeira Island, \\ Portugal \\ ${ }^{4}$ Laboratório Regional de Veterinária e Segurança Alimentar, Secretaria Regional do Ambiente e Recursos Naturais, \\ Funchal, Madeira Island, Portugal \\ ${ }^{5}$ Corresponding author (email: schifinoval@ hotmail.com)
}

ABSTRACT: Standard biochemical parameters were determined in wild juvenile loggerhead sea turtles Caretta caretta living offshore Madeira Island, northeast Atlantic. We analyzed the influence of age, sex, sea surface temperature, and body condition index on biochemical parameters including uric acid, total bilirubin, total cholesterol, creatinine kinase (CK), glucose, total protein, urea nitrogen, lactate dehydrogenase, aspartate aminotranspherase (AST), gammaglutamyl transferase (GGT), albumin, alkaline phosphatase (ALP), sodium (NA), potassium (K), chloride, calcium, phosphorus, and magnesium. Significant positive correlations were found between turtle body size and total cholesterol, total protein, and albumin. Total protein and the enzymes AST and CK were lower than reported levels in adults. Calcium levels were lower than those reported in adult or captive turtles, but similar to wild juveniles from Australian waters, and were interpreted as normal for this age category. These data may be useful to evaluate the health status of stranded or injured animals and to improve veterinary care at rehabilitation centers.

Key words: Blood biochemistry, Caretta caretta, juvenile pelagic stage, loggerhead sea turtle.

\section{INTRODUCTION}

Marine turtle species are considered endangered worldwide, with six of the seven species listed in threatened categories, the exception being the Australian flatback Natator depressus, which is listed as 'Data Deficient' (Polidoro et al., 2008). All species are impacted by human activities at every stage of their life cycle. Loggerheads observed around Madeira and Azores Archipelagos (Portugal) are small juveniles originating mainly from the southeastern nesting beaches in the USA (Bolten et al., 1998); they spend their first 6-12-yr-long pelagic life stage in oceanic foraging habitats (Bjorndal et al., 2000b, 2003) before migrating to neritic foraging habitats back on the western Atlantic. Therefore, they are considered visitors in these archipelagos where they forage and grow during the juvenile pelagic phase (Bolten, 2003; Oliveira et al., 2005).
Although research and conservation efforts have produced a large body of literature on loggerhead blood parameters (Frair and Shah, 1982; Lutz and DunbarCooper, 1987; Bolten et al., 1992, 1994), data on biochemical standard parameters for wild young individuals are scarce and recognized as necessary for different life stages or cohorts within a population (Deem et al., 2009). Two studies have been published on a similar pelagic population in the Canary Islands (Casal et al., 2009) but used rehabilitated turtles. More recently, Flint et al. (2010) performed a complete study in wild juvenile turtles from Australian waters.

The juvenile pelagic loggerhead population has been monitored on Madeira Island since 1994 (Dellinger, 2007), and includes very young turtles, which provides a good framework to build a reference for several health parameters. We provide a population baseline profile 
for blood biochemical parameters in juvenile loggerhead turtles from the North Atlantic. Additionally, we tested for correlations between these values and the individual's size (age), body condition index (BCI), and sea surface temperature (SST).

\section{MATERIALS AND METHODS}

Twenty-seven juvenile wild loggerhead sea turtles were captured south of Madeira Island, northeast Atlantic $\left(32^{\circ} 32^{\prime} \mathrm{N}, 16^{\circ} 59^{\prime} \mathrm{W}\right)$ between May and July 2006 using a scoop net (Dellinger et al., 1997) and brought into landbased facilities. They were clinically examined and acclimatized overnight in tanks filled with seawater (volume 75-1,000 l depending on the turtle's size). The tanks were kept at room temperature in a quiet area. Food was not provided and turtles were released unharmed after sampling, usually within $24 \mathrm{hr}$.

Blood samples were drawn early in the morning after capture, before any other manipulation, and were performed 12-18 hr after capture to avoid possible effects of acute handling stress (Gregory et al., 1996). Up to $4 \mathrm{ml}$ were collected from the dorsal post-occipital sinus into BD Vacutainers ${ }^{\mathrm{TM}}$ (Preanalytical Solutions, Belliver Industrial Estate, Plymouth, UK). Samples were clotted for $20-30 \mathrm{~min}$ and the serum decanted was removed into cryogenic vials and immediately frozen at -20 C. Serum analyses were performed 2-4 wk after blood samplings at the Veterinary and Food Safety Laboratory using an auto-analyzer (Spotchem EZ SP 4430, Arkray Factory Shanghai, Inc., Pudong, Shanghai, China), and the multiparametric analyzer Spotlyte (Menarini Diagnostics, Lisbon, Portugal) was used for ions. Seventeen biochemical parameters were evaluated (Table 1). Standard biometric procedures followed Bolten (1999); straight carapace length until notch SCL(nt), was used as body size indicator. Each turtle was tagged with a passive integrated transponder (PET) tag (Avid Technology, Inc., New York, New York, USA) in the right front flipper. A body condition index (body mass/SCL ${ }^{3}$; Bjorndal et al., 2000a) was calculated to evaluate the size vs. mass relationship. Sex determination was done through laparoscopy (Delgado et al., 2010). Sea surface temperature data were provided by the Harbor Administration Funchal, Madeira Island, Portugal.

Data were statistically analyzed with the SPSS 15.0 software package (IBM SPSS,
Armonk, New York, USA) and statistical significance accepted at $P<0.05$. Nonparametric statistical tests (Spearman and Pearson correlation) were used due to nonnormal distribution of data.

\section{RESULTS}

The 27 turtles (17 females, eight males, two undetermined) sampled averaged (mean \pm SD) 365.26 $289.46 \mathrm{~mm}$ long, $\mathrm{SCL}(\mathrm{nt})$, and weighed $9.01 \pm 5.33 \mathrm{~kg}$ (Table 1). Median BCI was 0.0158土 $0.001(n=27)$. None of the turtles presented external signs of fibropapilloma or other indicators of poor health such as emaciation, dehydration, or external parasites. Values and descriptive statistics for all biochemical and biometric parameters are presented in Table 1. Biochemical analyses could not be completed across all parameters and individuals due to limited sample volume. The sex-ratio was female-biased $(\sim 2: 1)$ and reflects this population's natural sex-ratio (Delgado et al., 2010). Sea surface temperature averaged 20.93 C (range=17.9-24.3). Only total cholesterol $(P=0.42)$, total protein $(P=0.72)$, and albumin $(P=0.60)$ were positively correlated with SCL.

\section{DISCUSSION}

Our results differ from those of Bolten et al. (1994), in which 22 of 26 blood parameters were significantly related to the turtle body size. These discrepancies may be due to the individuals' small size and, consequently, the immature status of the animals sampled in our study compared to those of Bolten et al. (1994) who sampled reproductively active adults. Considering only young turtles, a positive correlation between total protein and turtle size has been documented in juvenile green turtles Chelonia mydas (Bolten and Bjorndal, 1992).

Our data may be compared with those of Flint et al. (2010). Despite the different populations and geographic areas, both studies included animals from the same 
TABLE 1. Plasma biochemistry values and physical parameters for juvenile loggerhead sea turtles (Caretta caretta) captured from Madeira Island waters, May-July 2006.

\begin{tabular}{|c|c|c|c|c|}
\hline Variable $^{\mathrm{a}}$ & Mean value & Range & Median $^{\mathrm{b}}$ & $n$ \\
\hline Uric acid mg/dl & 1.40 & $1.00-2.40$ & 1.30 & 17 \\
\hline Total bilirubin mg/dl & 0.44 & $0.20-1.20$ & 0.35 & 18 \\
\hline Total cholesterol mg/dl & 105.83 & $60.00-200.00$ & 101.00 & 24 \\
\hline CK mg/dl & 0.40 & $0.30-0.50$ & 0.40 & 4 \\
\hline Glucose mg/dl & 130.27 & $71.00-197.00$ & 132.00 & 26 \\
\hline Total protein g/l & 2.93 & $2.10-4.00$ & 3.00 & 21 \\
\hline Urea nitrogen mg/dl & 183.85 & $62.06-344.54$ & 201.16 & 25 \\
\hline AST/SGOT UI/l & 93.94 & $13.00-238.00$ & 78.50 & 18 \\
\hline GGT U/l & 33.17 & $14.00-52.00$ & 31.50 & 6 \\
\hline Albumin $\mathrm{g} / \mathrm{l}$ & 1.38 & $1.00-2.00$ & 1.30 & 14 \\
\hline ALP U/1 & 74.53 & $51.00-120.00$ & 68.00 & 17 \\
\hline Sodium mMol/l & 149.62 & $135.90-166.20$ & 149.80 & 26 \\
\hline Potassium mMol/l & 4.68 & $3.70-7.30$ & 4.50 & 26 \\
\hline Chloride mMol/l & 116.09 & $100.00-136.00$ & 116.00 & 26 \\
\hline Calcium mg/dl & 4.90 & $3.10-7.10$ & 5.10 & 18 \\
\hline Phosphorus mg/dl & 7.24 & $3.30-13.40$ & 7.40 & 19 \\
\hline Magnesium mg/dl & 4.48 & $2.90-5.50$ & 4.70 & 10 \\
\hline $\operatorname{SCL}(\mathrm{nt})(\mathrm{mm})$ & 365.26 & $197.00-519.00$ & $\mathrm{NC}$ & 27 \\
\hline Weight $(\mathrm{kg})$ & 9.01 & 1.19-20.67 & $\mathrm{NC}$ & 26 \\
\hline BCI & 0.02 & $0.01-0.02$ & $\mathrm{NC}$ & 26 \\
\hline
\end{tabular}

${ }^{\mathrm{a}} \mathrm{CK}=$ creatinine kinase; AST/SGOT $=$ aspartate aminotransferase; GGT = gamma glutamyl-transferase; ALP $=$ alkaline phosphatase; SCL(nt) = straight carapace length until notch; BCI = body condition index.

${ }^{\mathrm{b}} \mathrm{NC}=$ not calculated.

species, wild condition, and life stage. A considerable difference was observed in the levels of total protein and albumin (2.93 and 1.38, respectively), which were lower in turtles from the Madeira Archipelago than the lower limit (29 and 5, respectively) found in turtles from Australian Pacific loggerheads. Due to the positive correlation between protein values and body size detected in the present study, the lower protein values observed in the Madeira population could be justified based on differences in the size of turtles from both areas. In our study, turtles averaged $365.3 \mathrm{~mm}$ long whereas those from Australia averaged $838 \mathrm{~mm}$.

According to general previous data, our results fell within the known ranges for total cholesterol (Campbell, 1996; Jacobson et al., 2007), albumin (George, 1997; Whitaker and Krum, 1999; Jacobson et al., 2007; Deem et al., 2009), chloride and phosphorus (Frye, 1991; Campbell, 1996; George, 1997; Whitaker and Krum, 1999;
Jacobson et al., 2007). Levels of uric acid (Campbell, 1996; Whitaker and Krum, 1999; Jacobson et al., 2007), CK (Campbell, 1996), glucose (Frye, 1991; Campbell, 1996; George, 1997; Whitaker and Krum, 1999; Jacobson et al., 2007), GGT (Jacobson et al., 2007; Deem et al., 2009), ALP (Campbell, 1996; George, 1997; Whitaker and Krum, 1999; Jacobson et al., 2007), and K (Frye, 1991; Campbell, 1996; George, 1997; Whitaker and Krum, 1999; Jacobson et al., 2007; Deem et al., 2009) were within the upper ranges referenced in several literature sources.

Values of total bilirubin and urea nitrogen were elevated (Campbell, 1996; Whitaker and Krum, 1999; Flint et al., 2010). Increased urea is usually observed in cases of kidney failure, dehydration, rich protein diet, or excessive protein breakdown. However, the elevated levels of urea nitrogen seem not to be related directly with diet because total protein levels were low, and even captive logger- 
heads fed the same diet also showed widely different urea values (Lutz and Dunbar-Cooper, 1987). Dehydration was not observed in the turtles we studied and, even in dehydrated turtles, total protein should be relatively high. As urea is a final product of protein catabolism, a plausible explanation is an increase of protein breakdown during acclimatization when food was not provided.

The enzymes AST and CK were slightly below known levels (Bolten et al., 1994; Campbell, 1996). Although below reference values, $\mathrm{Na}$ levels were close to normal ranges (Frye, 1991; Campbell, 1996; George, 1997; Whitaker and Krum, 1999; Jacobson et al., 2007) and between the reference values cited for juvenile turtles from Australian waters.

Some factors may justify the low total protein and calcium levels found in our study in relation to other studies. In turtles, nutrition, season, and environmental factors such as lead pollutants have a significant effect on serum protein (Frair and Shah, 1982). Postpelagic juvenile and adult loggerhead turtles are essentially carnivorous (Bjorndal, 1997), feeding mainly on benthic mollusks, crustaceans, and coelenterates (Dodd, 1988), whereas juveniles feed mainly on jellyfish (Bjorndal, 1997). As loggerheads grow, they appear to feed at progressively higher trophic levels, consuming food higher in nitrogen (Godley et al., 1998). Thus, the relatively low total protein levels found in our study may be attributed to the low energy density and protein content of jellyfish (Doyle et al., 2007) as well as to the lower trophic status (Godley et al., 1998). The significant correlation between carapace length and protein concentration was also previously described for all seven sea turtle species (Frair and Shah, 1982), except Natator depressus, which was not included in that study. Apart from the differences due to the very small body size of Madeiran turtles when compared to young turtles from the Pacific (Flint et al., 2010), we could not discard the effect of chronic exposure to heavy metal contamination on the plasma protein concentrations of the sea turtle population under study. Previous studies showed high levels of mercury and cadmium in the hepatic, kidney, skin, and muscle tissues of marine species from Madeira Archipelago (Afonso et al., 2007). Mercury is usually listed as a general protoplasmatic poison, and many of its effects are attributable to the fact that, as a heavy metal, it can act as a protein precipitant. An experiment performed in dogs verified that induced hypoproteinemia protected the animals against lethal mercuric chloride poisoning injuries (Holman and Donnelly, 1942), and this method is still used in human medicine (Koch and Trapp, 2006). As our objective was not focused on this subject, we recommend future studies to verify the relationship between heavy metal contamination and the oscillation on plasma proteins in this population.

Calcium levels were lower than in most previous studies (Campbell, 1996; ISIS, 1999; Whitaker and Krum, 1999) but similar to the values found in wild juveniles turtles from Australia (Flint et al., 2010). We believe the relatively low levels of this ion may be related to the age and the natural condition of these juvenile turtles, as most previous work was done on adult, subadult, or captive juvenile turtles. In the wild, physiologic condition is highly related to the ecologic niche and the probability of finding food. Juvenile turtles live in the open sea, do not dive as deep as the adults do, and feed mainly on jellyfish low in calcium, whereas adult turtles live near the coasts and have mollusks as an important item in their diet. Considering the poor calcium content of the diet and the active growth in this life stage, it is reasonable that the observed values of calcium are physiologically normal for wild juvenile turtles. Moreover, oscillations of serum calcium concentrations related to the individual's sex, or due to reproductive status as known for other reptiles (Dessauer, 1970; Allender et al., 2006), do not 
make sense in our sample. We suggest that the calcium levels presented at the juvenile stage are the baseline levels for this developmental stage, as opposed to much higher levels documented at older stages, and for specific physiologic stages such as reproduction (Lance, 1976).

Parameters such as glucose and chloride, $\mathrm{Na}$, and $\mathrm{K}$ were remarkable in their constancy and were within the reference intervals presented for wild young loggerhead turtles (Flint et al., 2010). These ions have a critical physiologic role for enzyme function (Hochachka and Somero, 1984), demonstrating the need for a relatively tight control of their levels in order to maintain physiologic homeostasis, in contrast to other biochemical parameters that can show wider oscillations while remaining within safe a physiologic range. Differences in many parameters, compared to the adult or subadult conspecifics, may also reflect ontogenetic and geographic differences in diet or digestive efficiency (Hamann et al., 2006).

Although the rather small sample size of this study may account for some of the high variance of most biochemical parameters, similar studies using large sample sizes have also reported high variability (Stamper et al., 2005), indicating that our findings reflect natural individual and population variability.

The use of reference values to diagnose or screen for disease implies that health is a relative concept; clinical examination, evaluation of laboratory data, and diagnostic imaging findings all require comparison to a reference standard (Walton, 2001). To our knowledge, this is one of the first studies assessing blood biochemical values in pelagic loggerhead populations and represents a unique dataset for wild, free-ranging oceanic juveniles of C. caretta from the North Atlantic Ocean. Additionally, our results point to a few differences that may have physiologic, ontogenetic significance between the juvenile oceanic developmental stage and older life stages.

\section{ACKNOWLEDGMENTS}

We thank the volunteers of Madeira's Marine Turtle Project and Renato Barradas (University of Madeira) for invaluable help during field and laboratory work and Al Segars (South Carolina Department of Natural Resources) and Ken Latimer (University of Georgia College of Veterinary Medicine) for technical advice. SST data were kindly provided by Funchal's Harbor Administration. Vladimir Ishchenko (Russian Herpetological Society) kindly provided some of the bibliography. C.D. is grateful to the Portuguese Science and Technology Foundation (grant SFRH/BD/8413/2002). Lauren Smith kindly reviewed the manuscript.

\section{LITERATURE CITED}

Afonso, C., H. M. Loureno, M. L. Abreu Dias, M. L. Nunes, and M. Castro. 2007. Contaminant metals in black scabbard fish (Aphanopus carbo) caught off Madeira and the Azores. Food Chemistry 101: 120-125.

Allender, M. C., M. A. Mitchell, C. A. Phillips, K. Gruszynski, and V. R. Beasley. 2006. Hematology, plasma biochemistry, and antibodies to select viruses in wild-caught eastern Massasauga rattlesnakes (Sistrurus catenatus catenatus) from Illinois. Journal of Wildlife Diseases 42: 107114.

BJoRndal, K. 1997. Foraging ecology and nutrition. In The biology of sea turtles, P. L. Lutz and J. A. Musick (eds.). CRC Press, Boca Raton, Florida. pp. 199-231.

, A. B. Bolten, and M. Chaloupka. 2000a. Green turtle somatic growth model: Evidence for density dependence. Ecological Applications 10: 269-282.

and H. R. Martins. 2000b. Somatic growth model of juvenile loggerhead sea turtles Caretta caretta: Duration of pelagic stage. Marine Ecology Progress Series 202: 265-272. , T. Dellinger, C. Delgado, and H. R. Martins. 2003. Compensatory growth in oceanic loggerhead sea turtles: Response to a stochastic environment. Ecology 84: 1237-1249.

Bolten, A. B. 1999. Techniques for measuring sea turtles. In Research and management techniques for the conservation of sea turtles, K. L. Eckert, K. A. Bjorndal, F. A. Abreu-Grobois, and M. Donnelly (eds.), IUCN/SSC Marine Turtle Specialist Group Publication No. 4. Washington, DC. pp. 110-114.

. 2003. Active swimmers-passive drifters: The oceanic juvenile stage of loggerheads in the Atlantic system. In Loggerhead sea turtles, A. B. Bolten and B. E. Witherington (eds.). Smithsonian Books, Washington, DC. pp. 63-78.

, AND K. A. BJoRndal. 1992. Blood profiles for 
a wild population of green turtles (Chelonia mydas) in the Southern Bahamas-size-specific and sex-specific relationships. Journal of Wildlife Diseases 28: 407-413.

, E. R. Jacobson, and K. A. BJorndal. 1992. Effects of anticoagulant and autoanalyzer on blood biochemical values of loggerhead sea turtles (Caretta caretta). American Journal of Veterinary Research 53: 2224-2227.

K. A. Bjorndal, P. J. Eliazar, and L. F. Gregory. 1994. Seasonal abundance, size distribution, and blood biochemical values of loggerheads (Caretta caretta) in Port Canaveral Ship Channel, Florida. NOAA Technical Memorandum NMFS SEFSC 353: 1-39.

, H. R. Martins, T. Dellinger, M. J.

Biscoito, S. E. Encalada, and B. W. Bowen. 1998. Transatlantic developmental migrations of loggerhead sea turtles demonstrated by mtDNA sequence analysis. Ecological Applications 8: 17.

Campbell, T. W. 1996. Sea turtle rehabilitation. In Reptile medicine and surgery, D. R. Mader (ed.). W. B. Saunders Co., Philadelphia, Pennsylvania. pp. 427-436.

Casal, A. B., M. Camacho, L. F. Lopez-Jurado, C. Juste, AND J. Oros. 2009. Comparative study of hematologic and plasma biochemical variables in eastern Atlantic juvenile and adult nesting loggerhead sea turtles (Caretta caretta). Veterinary Clinical Pathology 38: 213-218.

Deem, S. L., T. M. Norton, M. Mitchell, A. Segars, A. R. Alleman, C. Cray, R. H. Poppenga, M. Dodd, and W. B. Karesh. 2009. Comparison of blood values in foraging, nesting, and stranded loggerhead turtles (Caretta caretta) along the coast of Georgia, USA. Journal of Wildlife Diseases 45: 41-56.

Delgado, C., A. Canário, and T. Dellinger. 2010. Sex ratios of loggerhead sea turtles Caretta caretta during the juvenile pelagic stage. Marine Biology 157: 979-990. doi:910.1007/s00227/ 00009-01378-00228.

Dellinger, T. 2007. Behavioural ecology and conservation of oceanic-stage sea turtles: The Madeira Island loggerhead sea turtle project. In Marine turtles: Recovery of extinct populations, L. F. López Jurado and A. L. Loza (eds.). Instituto Canario Ciencias Marinas, Gran Canarias, Spain. pp. 95-109.

, J. Davenport, and P. Wirtz. 1997. Comparisons of social structure of Columbus crabs living on loggerhead sea turtles and inanimate flotsam. Journal of the Marine Biological Association of the UK 77: 185-194.

Dessauer, H. C. 1970. Blood chemistry of reptiles: Physiological and evolutionary aspects. In Biology of the Reptilia, C. Gans (ed.). Academic Press, New York, New York. pp. 1-72.

DoDD, C. K. 1988. Synopsis of the biological data on the loggerhead sea turtle Caretta caretta (Linnaeus 1758). US Fish and Wildlife Service Biological Report 88(14). U.S. Department of the Interior, US Fish and Wildlife Service, Washington, DC. pp. 110. www.fl.biology.usgs.gov/ Amphibians_and_Reptiles/LoggerheadSynopsis1988. pdf. Accessed March 2011.

Doyle, T. K., J. D. R. Houghton, R. McDevitt, J. Davenport, and G. C. Hays. 2007. The energy density of jellyfish: Estimates from bombcalorimetry and proximate-composition. Journal of Experimental Marine Biology and Ecology 343: 239-252.

Flint, M., J. M. Morton, C. J. Limpus, J. C. Patterson-Kane, and P. C. Mills. 2010. Reference intervals for plasma biochemical and hematologic measures in loggerhead sea turtles (Caretta caretta) from Moreton Bay, Australia. Journal of Wildlife Diseases 46: 731-741.

Frair, W., and B. K. Shah. 1982. Sea turtle blood serum protein concentrations correlated with carapace lengths. Comparative Biochemistry and Physiology 73a: 337-339.

Frye, F. L. 1991. Hematology as applied to clinical reptile medicine. In Biomedical and surgical aspects of captive reptile husbandry, B. Springs (ed.). Krieger Publishing Company, Malabar, Florida. pp. 211-224.

George, R. 1997. Health problems and disease in sea turtles. In The biology of sea turtles, P. L. Lutz and J. A. Musick (eds.). CRC Press, Boca Raton, Florida. pp. 363-385.

Godley, B. J., D. R. Thompson, S. Waldron, and R. W. Furness. 1998. The trophic status of marine turtles as determined by stable isotope analysis. Marine Ecology Progress Series 166: 277-284.

Gregory, L. F., T. S. Gross, A. B. Bolten, K. A. Bjorndal, and L. J. Guillette. 1996. Plasma corticosterone concentrations associated with acute captivity stress in wild loggerhead sea turtles (Caretta caretta). General and Comparative Endocrinology 104: 312-320.

Hamann, M., C. Schauble, T. Simon, and S. Evans. 2006. Demographic and health parameters of green sea turtles Chelonia mydas foraging in the Gulf of Carpentaria, Australia. Endangered Species Research 2: 81-88.

Hochachka, P. W., and G. N. Somero. 1984. Biochemical adaptation. Princeton University. Press, Princeton, New Jersey. pp. 53.

Holman, R. L., and G. L. Donnelly. 1942. Hypoproteinemia as protection against mercuric chloride injury in dogs. Journal of Experimental Medicine 76: 511-518.

International Species Information System(ISIS). 1999. International Species Information System physiological reference values for Caretta caretta. www.isis.org/Pages/default.aspx. Accessed April 2011.

Jacobson, E., K. Bjorndal, A. Bolten, R. Herren, 
G. Harman, and L. Wood. 2007. Establishing plasma biochemical and hematocrit reference intervals for sea turtles in Florida. www.accstr. ufl.edu/blood_chem.htm. Accessed August 2007.

Koch, M., and R. Trapp. 2006. Ethyl mercury poisoning during a protein A immunoadsorption treatment. American Journal of Kidney Diseases 47: 31-34.

Lance, V. 1976. Studies on the annual reproductive cycle of the female cobra, Naja naja: Seasonal variation in plasma inorganic ions. Comparative Biochemistry and Physiology 53: 285-289.

Lutz, P. L., And A. Dunbar-Cooper. 1987. Variations in the blood chemistry of the loggerhead sea turtle, Caretta caretta. Fishery Bulletin 85: 3743.

Oliveira, M. E., J. C. Brito, T. Dellinger, N. Ferrand De Almeida, A. Loureiro, H. R. Martins, J. Pargana, O. S. Paulo, P. Rito, and J. Teixeira. 2005. Caretta caretta Tartarugacomum. In Livro Vermelho dos Vertebrados de Portugal, M. J. Cabral, J. Almeida, P. R. Almeida, T. Dellinger, N. Ferrand de Almeida, M. E. Oliveira, J. M. Palmeirim, A. I. Queiroz, L. Rogado, and M. Santos-Reis (eds.). Instituto da Conservaão da Natureza, Lisboa, Portugal. pp. 123-124.

Polidoro, B. A., S. R. Livingstone, K. E. Carpenter, B. Hutchinson, R. B. Mast, N. Pilcher, Y.
Sadovy De Mitcheson, and S. Valenti. 2008. Status of the world's marine species. In 2008 review of the IUCN red list of threatened species, J. C. Vié, C. Hilton-Taylor, and S. N. Stuart (eds.). International Union for the Conservation of Nature, Gland, Switzerland, www. data.iucn.org/dbtw-wpd/edocs/RL-2009-001.pdf. Accessed April 2011. pp. 12.

Stamper, M. A., C. Harms, S. P. Epperly, J. BraunMcneill, L. Avens, and M. K. Stoskopf. 2005. Relationship between barnacle epibiotic load and hematologic parameters in loggerhead sea turtles (Caretta caretta): A comparison between migratory and residential animals in Pamlico Sound, North Carolina. Journal of Zoo and Wildlife Medicine 36: 635-641.

Walton, R. M. 2001. Establishing reference intervals: Health as a relative concept. Seminars in Avian and Exotic Pet Medicine 10: 66-71.

Whitaker, B. R., and H. Krum. 1999. Medical management of sea turtles in aquaria. Zoo and wild animal medicine: Current therapy, 4th Edition, M. E. Fowler and R. E. Miller (eds.). W. B. Saunders Co., Philadelphia, Pennsylvania. pp. 217-231.

Submitted for publication 25 October 2008. Accepted 9 February 2011. 